\title{
24hodinová mortalita seniorů akutně hospitalizovaných pro interní onemocnění - může být ovlivněna prítomností diabetu jako komorbidity?
}

\section{Jan Brož', Martina Nováková², Milan Kvapil² 'Interní klinika 2. LF UK a FN Motol, Praha ${ }^{2}$ Geriatrická interní klinika 2. LF UK a FN Motol, Praha}

Se zájmem jsme si přečetli výsledky originální studie mortality seniorů do 24. hodiny po přijetí k hospitalizaci pro interní onemocnění, publikovaný v 6. čísle letošního Vnitřního lékařství (1). Autoři analyzovali data 4361 pacientů starších 65 let hospitalizovaných v letech 2016-2018 na 1. klinice geriatrie LF UK a UN Bratislava. Výsledky ukázaly, že do 24 hodin od prrijetí zemřelo 2,3 \% pacientů, což činilo 15,6 \% ze všech úmrtí. Třemi nejčastějšími př́ičinami smrti mezi 25 identifikovanými nemocemi byl akutní infarkt myokardu (17,8 \%), bronchopneumonie $(14,9 \%)$ a sepse $(12,9 \%)$. Nebyla mezi nimi žádná akutní komplikace diabetu, a protože se analýza nevěnovala komorbiditám pacientů, nebyla stran diabetu uvedena ani tato data.

Podle odhadů Mezinárodní diabetické federace je mezi hospitalizovanými približně $18 \%$ pacientů s diabetem (2). Vzhledem k tomu, že podle Národního registru ČR byl v populaci nad 65 let věku podíl diabetiků vyšší než 30 \%, a ve věkové skupině 75-89 let osciloval kolem $35 \%$ (3), Ize předpokládat, že mezi hospitalizovanými seniory může toto čislo být dokonce vyšší než 18 \%. Napríklad v roce 2018 byl v USA poměr hospitalizací pacientů s diabetem vůči těm bez diabetu 1/2 (3) z diabetiků $95 \%$ byli pacienti s diabetem 2. typu a z nich 59,5\% bylo starších 64 let. Nejčastějšími důvody hospitalizace u nich byla septikemie, srdeční selhání, s diabetem spojená onemocnění, akutní infarkt myokardu a renální selhání, u pacientů s diabetem 1. typu byla na prvním místě s diabetem spojená onemocnění (4).

Zůstaneme-li v „před-covidové době“, pak studie sledující vliv diabetu na nemocniční mortalitu mají nehomogenní výsledky. Např́klad známá studie Umpierreze et al. prokázala pozitivní korelaci hyperglykemie (bez ohledu na anamnézu diabetu) s mortalitou u pacientů u hospitalizovaných pacientů (5).

Podle jiné studie byla nemocniční mortalita spojená infarktem myokardu v letech 1994-2006 u pacientů s diabetem vyšší, ale rozdíl se $\vee$ postupně snižoval z 1,24 $(95 \% \mathrm{Cl}, 1,16-1,32) \vee$ roce 1994 na 1,08
(95\% Cl, 0,99-1,19) v roce 2006 ( $>$ < 0,001 pro trend). Největší snížení mortality bylo nalezeno u žen s diabetem (17,9\% v roce 1994 vs. 8,4 \% $\checkmark$ roce 2006 ; $P<0,001)(6)$.

A napríklad relativně recentní studie z UK neprokázala vliv diabetu na mortalitu hospitalizovaných ve věku nad 65 let, diabetes dokonce mírně snižoval mortalitní šance (odds ratio) u diabetiků starších 80 let (7).

Vrátíme-li se k potenciálními vlivu hyperglykemie na mortalitu, pak je vhodné zmínit výsledky prưřezové populační česko-slovenské studie zabývající se kompenzací diabetiků léčených inzulinem. Ta je nedostatečná, podíl pacientů s uspokojivou kompenzací (HbA1c < $53 \%$ $\mathrm{mmol} / \mathrm{mol}$ ) byl v České republice $26,6 \%$ a ve Slovenské republice $36,4 \%$, průměrná glykemie v celém souboru byla $8,1 \pm 3,3$ mmol/l. U pacientů s diabetem 2. typu léčených inzulinem byl podíl těch s uspokojivou kompenzací v České republice 35,7\% a ve Slovenské republice 28,3\%, průměrná glykémie v celém souboru byla 7,8 $\pm 2,6$ mmol/I. $(8,9)$

Za zmínku v tomto ohledu též stojí výsledek studie zabývající se léčbou inzulinem v nemocnicích v České republice. Prưměrná hodnota glykemie u pacientů s diabetem 2. typu, bez ohledu na typ léčby, hospitalizovaných pro dekompenzaci onemocnění k převodu či úpravě inzulinoterapie byla při přijetí 17,35 $\pm 8,50 \mathrm{mmol} / \mathrm{l}$, a průměrná hodnota HbA1c byla $95,9 \pm 24,38 \mathrm{mmol} / \mathrm{mol}(10)$.

Lze tedy předpokládat, že většina pacientů s diabetem hospitalizovaných z jakéhokoliv důvodu pravděpodobně nebude mít optimální kompenzaci tohoto onemocnění a jejich mortalitní riziko tak může být vyšší.

Data o metabolické kompenzaci diabetu 2. typu léčeného perorálními antidiabetiky či GLP-1 agonisty ani v jedné z výše uvedených zemích nejsou k dispozici. Analýza údajů Všeobecné zdravotní pojištovny z České republiky, týkajících se tohoto segmentu pacientů, však ukazují, že celková mortalita se v této skupině u osob starších 50 let v letech 2003-2013 postupně snižovala a přiblížila se mortalitě obecné populace (11). 
E38 | KOMENTÁR̆E

Z4hodinová mortalita seniorů akutně hospitalizovaných pro interní onemocnění - může být ovlivněna př́tomností diabetu jako komorbidity?

Z výše uvedených dat je patrné, že diabetes by mohl ovlivňovat mortalitu pacientů z bratislavské studie. Dovolujeme si proto prísluš-

\section{LITERATURA}

1. Dúbrava M, Kiňová S, Jánošiová J. 24-hodinová mortalita seniorov akútne hospitalizovaných pre internistické ochorenie. Vnitr Lek. 2021; 67(6): E03-E07

2. International Diabetes Federation IDF diabetes altas, 9th edn Brussels: IDF, 2019. [online] [cit. 24. 10. 2021] Dostupné z: https://www.diabetesatlas.org/en/

3. Kvapil M. Počet diabetiků v České republice. VVV 2019; Supplementum, S34.

4. Diabetes-Related Inpatient Stays, 2018, [online] [cit. 23. 10. 2021] Dostupné z: https:// www.hcup-us.ahrq.gov/reports/statbriefs/sb279-Diabetes-Inpatient-Stays-2018.jsp

5. Umpierrez GE, Isaacs SD, Bazargan N, You X, Thaler LM, Kitabchi AE. Hyperglycemia: an independent marker of in-hospital mortality in patients with undiagnosed diabetes. J Clin Endocrinol Metab. 2002 Mar; 87(3): 978-982.

6. Gore MO, Patel MJ, Kosiborod M, Parsons LS, Khera A, de Lemos JA, Rogers WJ, Peterson ED, Canto JC, McGuire DK; National Registry of Myocardial Infarction Investigators. Diabetes mellitus and trends in hospital survival after myocardial infarction, 1994 to 2006 data from the national registry of myocardial infarction. Circ Cardiovasc Qual Outcomes. 2012 Nov; 5(6): 791-797. nou analýzu, pokud jsou data pro diabetes dostupná, doporučit. Její výsledek by dále obohatil dostupnou mezinárodní literaturu k tématu.

7. Smerdely P. Mortality is not increased with Diabetes in hospitalised very old adults: a multi-site review. BMC Geriatr. 2020 Dec 3; 20(1): 522.

8. Brož J, Janíčková Ždárská D, Urbanová J et al. Current Level of Glycemic Control and Clinical Inertia in Subjects Using Insulin for the Treatment of Type 1 and Type 2 Diabetes in the Czech Republic and the Slovak Republic: Results of a Multinational, Multicenter, Observational Survey (DIAINFORM). Diabetes Ther. 2018 Oct; 9(5): 1897-1906.

9. Brož J, Janíčková Ždárská D, Urbanová J et al. Jak dobře léčíme inzulinem v České republice a ve Slovenské republice Shrnutí výsledků a komentář originální česko-slovenské studie DIAINFORM. Vnitr Lek. 2019; 65(4): 279-283.

10. Brož J, Janíčková Ždárská D, Urbanová J et al. Insulin Management of Patients with Inadequately Controlled Type 2 Diabetes Admitted to Hospital: Titration Patterns and Frequency of Hypoglycemia as Results of a Prospective Observational Study (Hospital Study). Diabetes Ther. 2021 Jul; 12(7): 1799-1808.

11. Brož J, Honěk P, Dušek L, Pavlík T, Kvapil M. Mortalita pacientů s diabetes mellitus léčených perorálními antidiabetiky v České republice poklesla během let 2003-2013 a přiblížila se populačnímu průměru. Vnitr Lek 2015, 61(Suppl 3): 14-20. 